\title{
Meningkatkan Aktivitas dan Hasil Belajar Melalui Penerapan Model Controvesial Issues Pada Pelajaran IPS
}

\author{
Winda Maharani \\ STKIP PGRI METRO Ki Hajar Dewantara 38B Banjarrejo Lampung Timur \\ e-mail: maharaniwinda21@gmail.com
}

received : 8 March 2017

accepted : 10 April 2017

published : April 2017

\begin{abstract}
Increasing student's activities and learning outcomes by using controversial issues model in social studies. The aim of this study is for increasing the activities and outcomes of student's social studies learning by using Controversial Issues Model. The kind of this study is a classroom action research, with the data collection's forms are the observation and the test sheet. The analysis techniques used in this study are qualitative and quantitative analysis techniques. The results of this study showed that the implementation of Controversial Issues Model could increase the student's learning activities and outcomes. The percentage of student's mastery learning activities is $45 \%$ in the first cycle and become $75 \%$ in the second cycle. While at student's learning outcomes increased from $65 \%$ in the first cycle to $80 \%$ in the second cycle.
\end{abstract}

Keywords: controversial issues, activities and learning outcomes, social studies

Abstrak: Meningkatkan aktivitas dan hasil belajar melalui penerapan Model Controversial Issues pada pembelajaran IPS. Penelitian ini bertujuan untuk meningkatkan aktivitas dan hasil belajar IPS siswa dengan menerapkan model controversial issues. Jenis penelitian ini adalah penelitian tindakan kelas, alat pengumpul data penelitian berupa lembar observasi dan soal tes. Teknik analisis yang digunakan dalam penelitian ini adalah teknik analisis kualitatif dan kuantitatif. Hasil penelitian menunjukkan bahwa penerapan model controversial issues pada pembelajaran IPS dapat meningkatkan aktivitas dan hasil belajar siswa. Persentase ketuntasan aktivitas belajar siswa siklus I adalah $45 \%$ meningkat pada siklus II menjadi $75 \%$. Hasil belajar siswa juga meningkat dari $65 \%$ pada siklus I menjadi $80 \%$ pada siklus II.

Kata kunci: controversial issues, aktivitas dan hasil belajar, IPS. 


\section{PENDAHULUAN}

Proses pembelajaran IPS yang efektif terjadi apabila guru mampu menggali informasi dan pengetahuan melalui fakta dan kejadian yang berhubungan dengan konsep kurikulum. Untuk mewujudkan hal itu maka seorang guru harus mampu memilih model pembelajaran yang memungkinkan pembelajaran berlangsung dengan menarik, sebab model mengajar merupakan sarana interaksi guru dengan siswa di dalam proses belajar mengajar. Dengan demikian, yang perlu diperhatikan adalah ketepatan model mengajar yang dipilih dengan memperhatikan tujuan, jenis, sifat materi pelajaran dan kemampuan guru dalam memahami dan melaksanakan metode tersebut (Usman dan Setyawati 1993:120).

Berdasarkan hasil observasi dan wawancara dengan guru kelas V di SD Negeri 7 Metro Utara, dalam pembelajaran IPS, proses pembelajaran masih terpusat pada guru, sehingga proses pembelajaran kurang menarik, siswa kurang aktif, dan iklim belajar tidak cukup kondusif untuk mendukung pencapaian prestasi belajar siswa, dimana nilai rata-rata siswa hanya mencapai 60 dan KKM yang ditentukan adalah 70 .

Sedangkan bila dianalisis karakteristik pembelajaran IPS di sekolah dasar, maka secara umum diperoleh gambaran bahwa perhatian pembelajaran IPS adalah untuk membangun pengetahuan siswa menjadi warga negara yang baik yang memiliki jiwa sosial. Isu-isu dalam kehidupan manusia yang senantiasa muncul serta memiliki pengaruh yang sangat penting. Oleh karena itu, menurut Hassan (dalam Komalasari, 2013:204) melalui pembelajaran IPS dengan penerapan model controversial issues para siswa diharapkan: (1) memahami dan menyadari betapa interaksi antara pelaku dengan lingkungan dan peristiwa yang ditimbulkan, didalam sejumlahnya mengandung sejumlah isu dan persoalan, dan isu atau persoalan ada alternatif penyelesaiannya yang merupakan interaksi antara pelaku, (2) memberi kesempatan yang luas pada siswa untuk berperan sebagai warga negara dan masyarakat dengan berpartisipasi dalam memecahkan berbagai isu di lingkungan yang terdekat dengan kehidupannya. Artinya setiap orang yang melakukan sesuatu tindakan di dalam masyarakat akan terdapat beberapa permasalahan yang akan muncul sehingga menimbulkan isu permasalahan tersebut dan akan ada penyelesaian masalah itu.

Dalam tingkat awal sebaliknya pengajaran controversial issues tidak terlalu mengungkapkan banyak isu yang berbeda. Dua atau tiga isu yang berbeda sudah dapat dianggap cukup. Semakin lama semakin mampu siswa yang berbeda lebih banyak maka jumlah controversial issues pun dapat ditingkatkan. Meskipun demikian tetap harus diingat bahwa jumlah ini

Tabel 1. Data Prasurvei Hasil Ulangan Harian Mata Pelajaran IPS Siswa Kelas V SD Negeri 7 Metro Utara

\begin{tabular}{|c|c|c|c|c|}
\hline No & Nilai & Kriteria & Jumlah Siswa & Presentase \\
\hline 1 & $\geq 70$ & Tuntas & 7 & 35,00 \\
\hline 2 & $<70$ & Belum tuntas & 13 & 65,00 \\
\hline \multicolumn{3}{|c|}{ Jumlah } & 20 & 100 \\
\hline
\end{tabular}

Sumber : Data Nilai Hasil Tes ulangan harian I Mata Pelajaran IPS Kelas V Semester Ganjil SD Negeri 7 Metro Utara TP 2016/2017. 
bukan menjadi tujuan utama, tetapi kemampuan siswa dalam berbeda pendapat dan toleransi berpendapat merupakan tujuan (Hassan dalam Komalasari, 2013:204). Artinya semakin banyak siswa yang dapat memberikan tanggapan terhadap isu yang diberikan maka kemampuan siswa dapat ditingkatkan dengan memberikan isu yang lebih banyak lagi. Oleh karena itu perlu diadakan penelitian tindakan kelas untuk membuktikan bahwa model controversial issues (CI) dapat meningkatkan aktivitas dan hasil siswa khususnya pada mata pelajaran Ilmu Pengetahuan Sosial (IPS) di kelas V sekolah dasar negeri 7 Metro Utara.

Controversial issues adalah model pembelajaran yang menyajikan sesuatu isu atau masalah aktual yang menimbulkan pro-kontra, melalui perbedaan pendapat tentang sesuatu isu atau masalah, maka materi controversial issues secara langsung membangkitkan kemampuan berfikir kritis siswa selain itu controversial issues adalah sesuatu yang sudah diterima oleh seseorang atau kelompok, tetapi juga mudah di tolak oleh orang atau kelompok lain (Muessing dalam Komalasari 2013:60). Kecenderungan seseorang atau kelompok untuk memihak didasari oleh pertimbangan-pertimbangan pemikiran tertentu. Apabila orang tidak sependapat, atau terbentuk opini yang bertentangan dalam suatu hal, maka itulah yang disebut controversial issues (Wiriaatmadja dalam Komalasari, 2013:269) controversial issues dalam IPS membahas topik yang tidak sependapat, mendengarkan opini orang lain, mencari informasi, menyadari adanya perbedaan, membangun empati dan pengertian, untuk kemudian mengambil kesimpulan.

Dari definisi para ahli di atas dapat dilihat bahwa model pembelajaran ini memiliki potensi besar untuk menstimulus daya berpikir siswa yang nantinya akan berpengaruh pada peningkatan pengetahuan dan keterampilan mereka. Menurut Hamalik (2011: 155) hasil belajar tampak sebagai terjadinya perubahan tingkah laku pada diri siswa, yang dapat diamati dan diukur dalam perubahan pengetahuan, sikap, dan keterampilan. Sejalan dengan itu Bloom (dalam Suparman, 2012: 34) menyatakan perubahan perilaku yang terjadi sebagai hasil belajar meliputi perubahan dalam kawasan (domain) kognitif, afektif dan psikomotor, beserta tingkatan kognitif dan aspekaspeknya. Menurut Dimyati dan Mudjiono (2006: 4-5) dampak pembelajaran adalah hasil yang dapat diukur seperti tertuang dalam raport, angka dalam ijazah atau kemampuan meloncat setelah latihan. Dari uraian-uraian tersebut jelas bahwa suatu proses belajar mengajar pada akhirnya akan menghasilkan kemampuan siswa yang mencakup pengetahuan, sikap dan keterampilan.

Selain itu, model pembelajaran CI ini dapat mendorong siswa untuk aktif dalam kegiatan pembelajaran karena strukturnya yang meminta siswa untuk berkelompok. Terdapat dua aktivitas siswa dalam kegiatan pembelajaran, yaitu aktivitas yang diinginkan (on task), dan aktivitas yang tidak diinginkan (off task). Aktivitas on task antara lain bertanya pada guru, menjawab pertanyaan guru, menjawab pertanyaan dari teman, memberikan pendapat dalam diskusi, ketepatan mengumpulkan tugas dan sebagainya. Sedangkan aktivitas off task antara lain ngobrol, mengganggu teman, keluar masuk kelas, melamun/mengantuk, mainan HP dan sebagainya, (Sunyono, 2009 : 18) Sardiman (2004: 95) mengungkapkan bahwa belajar yang berhasil pasti melakukan aktivitas, baik aktivitas fisik maupun psikis.

Aktivitas fisik adalah siswa giat aktif dengan anggota badan, membuat sesuatu, bermain ataupun bekerja. Sedangkan aktivitas psikis (kejiwaan) adalah siswa yang daya jiwanya bekerja sebanyak-banyaknya atau banyak berfungsi dalam rangka pengajaran untuk mendapatkan pengajaran yang optimal sekaligus mengikuti proses pengajaran (proses perolehan hasil pelajaran) secara aktif. 
Berdasarkan pendapat para ahli tersebut dapat disimpulkan bahwa yang dimaksud dengan aktivitas belajar adalah segala kegiatan yang melibatkan kerja fikiran dan badan terutama dalam hal kegiatan belajar mengajar untuk mencapai tujuan yang ditetapkan. Semakin banyak aktivitas yang dilakukan oleh siswa, diharapkan siswa akan semakin memahami dan menguasai materi pelajaran yang disampaikan guru, dengan demikian hasil belajar siswa akan meningkat.

Menurut Wiriaatmadja (dalam Komalasari 2013:262), keuntungan menggunakan model pembelajaran controversial issues adalah :

a. Mengajarkan kepada siswa keterampilan akademis untuk membuat hipotesis, mengumpulkan evidensi, menganalisis data, dan menyajikan hasil inkuiri.

b. Melatih siswa untuk menghadapi kehidupan sosial yang kompleks dengan keterampilan berkomunikasi, menanamkan rasa empati, mempengaruhi orang lain, toleransi, bekerjasama, dan lain - lain.

c. Karena isu-isu yang di bahas berguna untuk mempelajari studi kasus dengan memahami penggunaan konsep, generalisasi, dan teori ilmu-ilmu sosial.

Selain itu, Wiriaatmadja (dalam Komalasari 2013:61) mengemukakan langkah-langkah pembelajaran dengan menggunakan controversial issues adalah sebagai berikut :

a. Guru dan siswa melakukan brainstorming mengenai controversial issues yang akan dibahas.

b. Siswa berkelompok memilih salah satu kasus untuk dikaji.

c. Siswa melakukan inkuiri, mengundang narasumber, membaca buku, mengumpulkan informasi lain.

d. Siswa menyajikan atau mendiskusikan hasil inkuiri, mengajukan argumentasi, mendengarkan couter-argument atau opini lain. e. Siswa menerapkan konsep, generalisasi, teori ilmu sosial untukakademis menganalisis permasalahan.

Berdasarkan langkah-langkah menurut para ahli, maka peneliti dapat menggunakan langkah-langkah sebagai berikut:

1. Guru menyajikan materi yang menggandung controversial issues. Penyajian materi dilakukan dengan penjelasan guru.

2. Guru melakukan tanya jawab kepada siswa mengenai controversial issues yang akan dibahas.

3. Siswa berkelompok, lalu setiap siswa memilih salah satu kasus untuk dikaji yang telah diberikan oleh guru.

4. Siswa mengumpulkan informasi dari membaca buku atau melakukan wawancara.

5. Siswa mendiskusikan informasi yang telah diperoleh.

6. Siswa menyajikan hasil diskusi dan mendengarkan opini dari kelompok lain.

7. Guru memberikan kesimpulan terhadap hasil diskusi dari controversial issues yang telah dikaji oleh siswa.

Maka dapat disimpulkan bahwa penelitian ini bertujuan untuk meningkatkan aktivitas dan hasil belajar siswa kelas V SDN 7 Metro Utara pada mata pelajaran IPS dengan menerapkan model controversial issues.

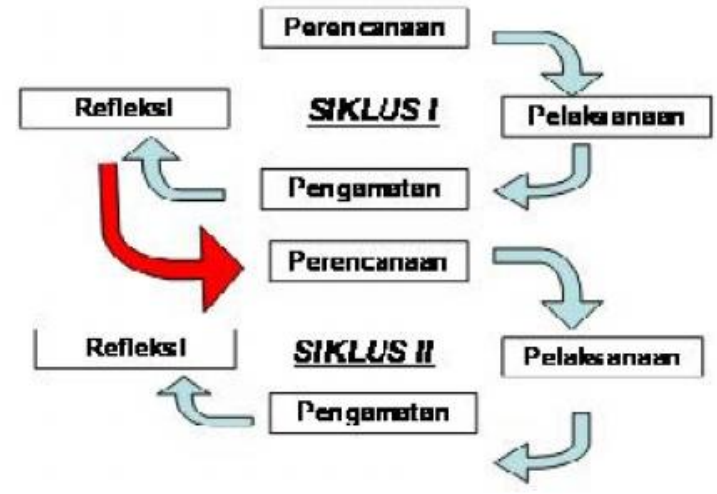

Gambar 1. Modifikasi dari Arikunto (2012: 16) 
Tabel 2. Aspek aktivitas yang diamati

\begin{tabular}{ll}
\hline Aspek aktivitas & Indikator \\
Yang diamati & 1.Aktif mengajukan pertanyaan. \\
& 2.Semangat dalam belajar \\
Keaktifan & 3.Keterlibatan dalam pembelajaran \\
& 4.Aktif dalam pembelajaran \\
& 5.Kesamaan pendapat \\
& 6.Kekompakan dalam kelompok \\
Kerja sama & 7.Penyatuan pendapat \\
& 8.Tidak pasif dalam kelompok \\
\hline
\end{tabular}

(Sumber: Modifikasi Mulyasa, 2011:147)

\section{METODE}

Jenis penelitian adalah penelitian tindakan kelas, penelitian tindakan kelas merupakan kegiatan penelitian yang dilakukan di dalam kelas laporan kegiatan nyata yang dilakukan guru dalam upaya memperbaiki proses pembelajaran di kelas dimana guru bertugas (Arikunto, 2011:2). Subjek penelitian ini adalah siswa kelas V SDN 7 Metro Utara sebanyak 20 siswa yang terdiri dari 12 siswa putra dan 8 siswa putri. Penelitian ini dilakukan di SDN 7 Metro Utara Kota Metro pada semester ganjil tahun ajaran 2016/2017 dengan menyesuaikan jam pelajaran IPS kelas V SDN 7 Metro Utara.

Tahapan penelitian tindakan kelas yang digunakan mengikuti modifikasi dari Arikunto, yang meliputi perencanaan tindakan (planning), penerapan tindakan (action), mengobservasi dan mengevaluasi proses dan hasil tindakan (observation and evaluation), dan melakukan refleksi (reflecting) dan seterusnya sampai perbaikan atau peningkatan yang diharapkan. Alur penelitian ini tertera pada gambar 1. Instrumen yang digunakan berupa lembar observasi untuk aktivitas belajar siswa dan juga soal tes untuk mengetahui hasil belajarkognitif serta mengetahui ketercapaian indikator pembelajaran melalui dalam model controversial issues. Aspek aktivitas yang dinilai dalam penelitian ini adalah keaktifan dan kerjasama. Indikator aspek aktivitas keaktifan dan kerjasama dapat dilihat pada tabel 2 .

Sedangkan untuk tes kognitif yang diberikan mengacu pada kisi-kisi yang telah dipersiapkan dapat dilihat pada tabel 3.

Teknik analisis data yang digunakan dalam penelitian ini berupa teknik analisis kualitatif dan kuantitatif. Menurut Sugiyono (2015: 89) analisis data adalah: Proses mencari dan menyususun secara sistematis data yang diperoleh dari hasil wawancara, catatan lapangan, observasi, dan dokumentasi, dengan cara mengorganisasikan data kedalam kategori, menjabarkan kedalam unit-unit, melakukan sintesa, menyusun kedalam pola, memilih mana yang penting dan yang akan dipelajari, dan membuat kesimpulan sehingga mudah dipahami diri sendiri dan orang lain. Analisis data kualitatif bersifat induktif, yaitu analisis data berdasarkan data yang diperoleh selanjutnya dikembangkan 
menjadi hipotesis. Sedangkan data kuantitaif dalam menganalisis hasil observasi aktivitas guru dan aktivitas siswa dengan cara menghitung persentase setiap kategori untuk setiap tindakan.

Indikator keberhasilan yang ditetapkan oleh peneliti adalah sebesar $75 \%$ dengan merujuk kategori keberhasilan menurut Djamarah (2000: 97) urutan keberhasilan pembelajaran adalah sebagai berikut:
1. Istimewa/maksimal apabila seluruh bahan pelajaran yang diajarkan dapat dikuasai oleh siswa.

2. Baik sekali/optimal apabila sebagian besar (76\% s.d. 99\%) bahan pelajaran yang diajarkan dapat dikuasai oleh siswa.

3. Baik/minimal apabila bahan pelajaran yang diajarkan hanya $60 \%$ s.d. $75 \%$ saja dikuasai oleh siswa.

4. Kurang apabila bahan pelajaran yang diajarkan kurang dari $60 \%$ saja dikuasai oleh siswa.

Tabel 3. Kisi-kisi soal tes kognitif

\begin{tabular}{lll}
\hline No & Kompetensi Dasar & Kriteria \\
\hline 1 & 1.4 Menghargai keragaman suku & Menyebutkan suku yang sekarang \\
& bangsa dan budaya di Indonesia & $\begin{array}{l}\text { tinggal di provinsi lampung } \\
\text { Menjelaskan manfaat sikap saling } \\
\text { menghormati antar suku bangsa }\end{array}$ \\
2 & 1.5 Mengenal jenis-jenis usaha dan & $\begin{array}{l}\text { Menyebutkan contoh jenis usaha } \\
\text { yang ada di sekitar rumah } \\
\text { kegiatan ekonomi di Indonesia }\end{array}$ \\
& & $\begin{array}{l}\text { Menjelaskan penyebab harga } \\
\text { sembako naik }\end{array}$ \\
\hline
\end{tabular}

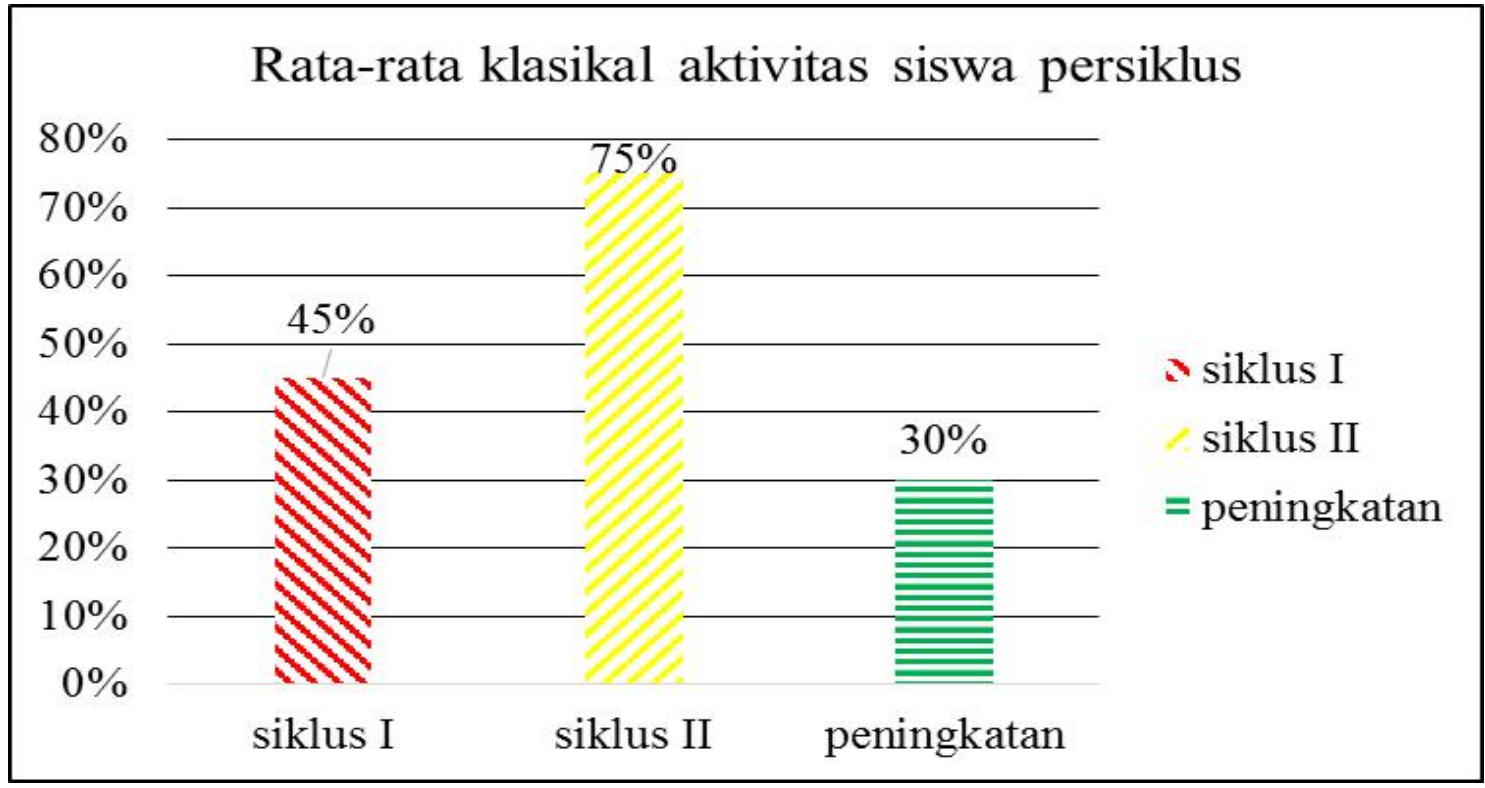

Gambar 2. Grafik nilai rata-rata aktivitas siswa persiklus 


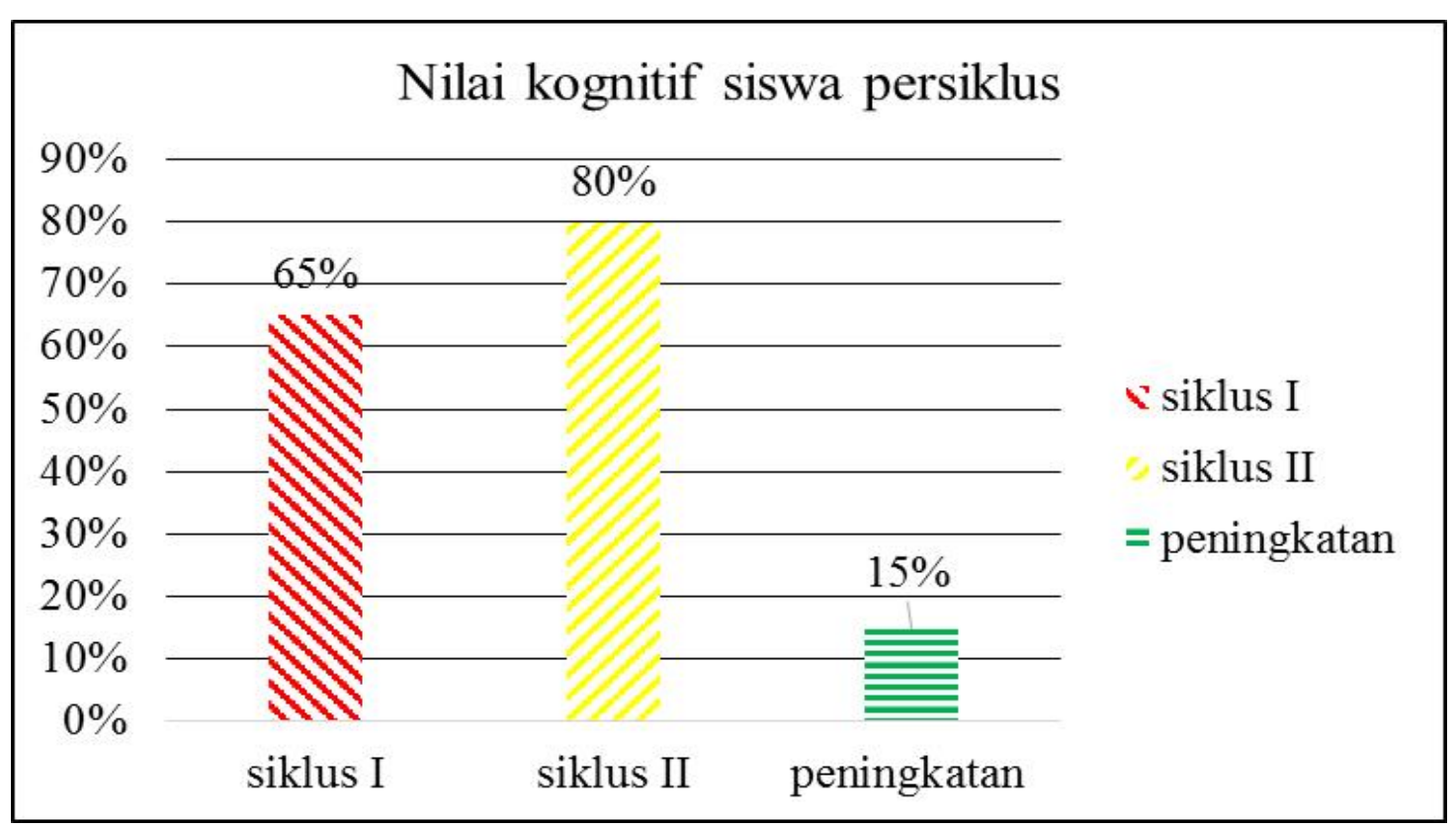

Gambar 3. Grafik nilai kognitif siswa persiklus

\section{HASIL DAN PEMBAHASAN}

Siklus dalam penelitian ini dilaksanakan 2 kali pertemuan pada setiap siklusnya. Pada pertemuan 1 digunakan untuk membahas materi, menerapkan model controversial issues serta mengerjakan LKS dan pada pertemuan 2 digunakan untuk menerapkan model controversial issues dan diakhiri dengan pemberian soal tes.

Pada siklus I pertemuan 1 materi yang diberikan adalah seputar keanekaragaman suku yang terdapat di Provinsi Lampung, lanjut pada siklus I pertemuan 2 yaitu seputar manfaat sikap saling menghormati antar suku bangsa.

Sedangkan pada siklus II pertemuan 1 materi yang diberikan adalah seputar contoh jenis usaha yang ada di sekitar rumah dan dilanjutkan dengan materi seputar penyebab harga sembako naik pada siklus II pertemuan 2. Hasil dari penelitian ini berupa deskripsi aktivitas belajar siswa dan juga hasil tes siswa per siklus. Dari 2 siklus diperoleh data aktivitas belajar siswa pada gambar 2. Berdasarkan grafik tersebut, data aktivitas belajar siswa terlihat meningkat dari $45 \%$ pada siklus I menjadi $75 \%$ pada siklus II. Hal ini membuktikan bahwa model controversial issues dapat meningkatkan aktivitas siswa dalam proses pembelajaran. Sedangkan untuk data hasil belajar siswa terlihat pada grafik pada gambar 3 .

Berdasarkan grafik tersebut, terlihat pada siklus I bahwa persentase siswa tuntas sebesar 65\% (13 siswa). Selanjutnya pada siklus II mencapai persentase siswa tuntas sebesar $80 \%$ (16 siswa). Peningkatan ketuntasan klasikal siklus I menuju siklus II sebesar $15 \%$. Lebih rinci mengenai peningkatan aktivitas dan hasil belajar siswa dapat dilihat pada tabel 4.

Pada siklus I, siswa masih tampak kesulitan untuk menyampaikan hasil diskusi dan berkerja sama di dalam kelompok, siswa masih kesulitan memberikan ide, pendapat atau saran dalam kelompok, siswa masih kesulitan untuk mencari informasi atau data yang diperlukan dalam menyelesaikan tugas kelompok yang diberikan, 
Tabel 4. Rekapitulasi Aktivitas Belajar Siswa

\begin{tabular}{lcc}
\hline \multirow{2}{*}{ Keterangan } & \multicolumn{2}{c}{ Siklus } \\
\cline { 2 - 3 } & Siklus I & Siklus II \\
\cline { 2 - 3 } Jumlah skor & 1.296 & 1.568 \\
Nilai rata-rata & 64,8 & 78,4 \\
Peningkatan rata-rata & & 13,6 \\
Persentase klasikal & $45 \%$ & $75 \%$ \\
Kriteria & Cukup Aktif & Aktif \\
\hline
\end{tabular}

Tabel 5. Rekapitulasi Peningkatan Hasil Belajar Siswa

\begin{tabular}{|c|c|c|}
\hline Keterangan & Siklus I & Siklus II \\
\hline Jumlah nilai & 1220 & 1.430 \\
\hline Nilai rata-rata & 61 & 71,5 \\
\hline Jumlah siswa tuntas & 13 & 16 \\
\hline Jumlah siswa belum tuntas & 7 & 4 \\
\hline Persentase ketuntasan klasikal & $65 \%$ & $80 \%$ \\
\hline Kategori & Sedang & Tinggi \\
\hline Peningkatan klasikal & & \\
\hline
\end{tabular}

siswa masih kesulitan untuk menanggapi pendapat yang dikemukakan oleh teman atau kelompok lain. Sementara itu, terdapat beberapa siswa yang masih ribut dan mengobrol di dalam kelas saat kelompok lain sedang mempresentasikan hasil diskusinya.

Pada proses pembelajaran siklus II, terlihat bahwa siswa lebih antusias dan bersemangat dalam belajar. Sebagian besar anggota dalam kelompok, sudah berusaha untuk saling bekerjasama, saling memberikan pendaptnya. Tingkat pemahaman siswa terhadap konsep materi melalui LKS sudah semakin baik dan siswa sudah menumbuhkan rasa ingin tahunya dan tidak malu dalam bertanya.

Sesuai dengan tabel 5, pada siklus I nilai rata-rata kelas 61 dengan persentase 13 siswa tuntas sebesar $65 \%$ memperoleh kriteria sedang dan 7 siswa yang tidak tuntas yaitu sebesar $35 \%$. Selanjutnya pada siklus II nilai rata-rata kelas mencapai 71,5 dengan persentase 16 siswa tuntas $80 \%$ dengan kriteria tinggi dan 4 siswa yang tidak tuntas yaitu sebesar 20\%. Peningkatan ketuntasan klasikal siklus I menuju siklus II sebesar $15 \%$.

Konsep pembelajaran dengan menerapkan model controversial issues memang berperan dalam peningkatan aktivitas dan hasil belajar siswa.

Model controversial issues mengarahkan siswa untuk saling bekerjasama, membangun pengetahuannya sendiri dengan mengaitkan pengetahuan dan pengalaman dalam konteks dunia nyata. Sehingga, kegiatan pembelajaran yang dilakukan mengarahkan siswa untuk terlibat aktif dalam memperoleh pengetahuan dan pengalaman yang bermakna. Hal ini sejalan dengan pemikiran Kunandar (2010) yang antara lain menyimpulkan bahwa keterlibatan siswa dalam bentuk sikap, minat, perhatian, dan aktivitas dalam kegiatan pembelajaran dapat menunjang keberhasilan proses belajar mengajar meliputi memperhatikan penjelasan guru atau teman, memberikan ide, usul atau saran dalam kelompok, menanggapi pendapat yang dikemukakan oleh teman atau kelompok lain, 
bekerjasama dalam diskusi kelompok, dan menyampaikan hasil diskusi dalam kelompok.

Dari hasil penelitian dan analisis, dapat disimpulkan bahwa dengan menerapkan model controversial issues, dapat meningkatkan aktivitas dan hasil belajar siswa sehingga seluruh aspek dalam kegiatan pembelajaran yang saling berkaitan antara satu dengan yang lainnya dapat didukung keberhasilannya.

\section{SIMPULAN}

Berdasarkan hasil temuan dan pembahasan yang dilakukan, dapat disimpulkan bahwa penelitian tindakan kelas menggunakan model pembelajaran controversial issues dapat meningkatkan aktivitas belajar IPS siswa kelas V SD Negeri 7 Metro Utara, penelitian tindakan kelas menggunakan model pembelajaran controversial issues dapat meningkatkan hasil belajar IPS siswa kelas V SD Negeri 7 Metro Utara, dan pembelajaran dapat berjalan lebih optimal dengan menggunakan model controversial issues.

\section{DAFTAR RUJUKAN}

Arikunto, Suharsimi dkk. 2012. Penelitian Tindakan Kelas. Bumi Aksara. Jakarta.

Arikunto, Suharsimi.2011.Penelitian Tindakan Kelas. Jakarta: Bumi Aksara.

Djamarah, Syaiful Bahri. 2000. Guru dan Anak Didik dalam Interaksi Edukatif. Jakarta: Rineka Cipta. Guru dalam jabatan pendidikan dan pelatihan). FKIP Universitas Lampung.

Gusmila,Nuraharmi dan Nora. 2009. Penerapan Model Controversial Issues untuk Meningkatkan Aktivitas Belajar PKn
Siswa Kelas IV SDN 07 Koto Sani

Kabupaten Solok.Jurnal Universitas Bung Hatta 2(1):1-14.

Hamalik. 2011.Perencanaan Pengajaran Berdasarkan Pendekatan Sistem. Jakarta. Bumi Aksara

Komalasari, 2013. Pembelajaran Kontekstual: Konsep dan aplikasi. Bandung. PT. Refika Aditama.

Komalasari,K. 2008. Peningkatan Kemampuan Berpikir Kritis Siswa Dalam PKn Melalui Penerapan Model Controversial Issues. Jurnal Penelitian 8 (1).406-416.

Kunandar. 2014. Langkah Mudah Penelitian

Tindakan Kelas Sebagai

Pengembangan Profesi. Jakarta. PT.

RajaGrafindo Persada.

Mulyasa. 2014. Menjadi Guru Profesional:

Menciptakan Pembelajaran Kreatif dan

Menyenangkan. Bandung: PT. Remaja Rosdakarya.

Ni.Md.Winursit, I Wyn. Wiarta dan I Wyn. Sujana. 2014. Pembelajaran Kontekstual Berbasis Controversial Issues Berpengaruh Terhadap Hasil Belajar Ips Siswa Kelas V SD DIGugus II Mengwi Kabupaten Bandung. Jurnal Mimbar PGSD Universitas Pendidikan Ganesha Jurusan PGSD.2(1):1-10.

Sugiyono. 2015. Metode Penelitia Pendidikan. Bandung: Alfabeta.

Sunyono. 2009. Perencanaan PTK dan Penulisan Karya Ilmiah (Modul sertifikasi Suparman.2012. Desain Intruksional Modern.Jakarta.Erlangga.

Usman \& Setyawati. 1993. Model-model pembelajaran. Jakarta. Raja Grafindo persada. 